\title{
Peter Abrahams of South Africa: Learning to Read (in) the Global 1930s
}

\section{Jason Frydman}

To cite this article: Jason Frydman (2020) Peter Abrahams of South Africa: Learning to Read (in) the Global 1930s, Critical Arts, 34:3, 9-22, DOI: 10.1080/02560046.2020.1729217

To link to this article: https://doi.org/10.1080/02560046.2020.1729217

\section{曲 Published online: 01 Apr 2020.}

5 Submit your article to this journal $\square$

\section{山 Article views: 15}

Q View related articles ¿

\section{View Crossmark data \ulcorner}




\title{
Peter Abrahams of South Africa: Learning to Read (in) the Global 1930s
}

\author{
Jason Frydman \\ English Department, CUNY Brooklyn College, Brooklyn, NY, USA
}

\begin{abstract}
Born poor, the material and ideological networks that propelled Peter Abrahams to literacy in 1930s South Africa lay bare how white liberalism, Pan-Africanism, and Marxism all overlapped as well as contradicted one another in the global 1930s. The confluences and contradictions of these currents of thought, artistic production, and political action structure not only Abrahams's early life and writing, they haunt the Cold War-era writings which established Abrahams's international reputation, a treacherous era which saw many of his 1930s peers sink into impoverished obscurity. Abrahams's perduring reputation depended on his precarious ability to write and act from the ironic institutional conjunctures that brought together a fragile constellation of networks and positions, derived from the Popular Front politics of the global 1930s, teetering on the edge of collapse and mutual negation. Yet anachronistic readings of his political and literary entanglements, and a failure to take seriously the sites of his early literacy and youthful writings, have manhandled this fragility, overwriting as a watery liberalism his generative merging of Pan-Africanism and Marxism that remains relevant today.
\end{abstract}

\section{KEYWORDS}

1930s; Popular Front; Global Left; South African literature; Peter Abrahams; marxism;

Pan-Africanism; white

liberalism

As of 2019, the 1946 novel Mine Boy, "the first African novel written in English to attract international attention", long published by the Heinemann African Writers series, represents the only book of Peter Abrahams to remain in print (Ogungbesang 1979, 21). There are currently no plans to reprint any of his other 13 books (two volumes of poetry, a collection of short stories, six novels, two memoirs, one travel book, and one survey of late-colonial Jamaica). While the centenary of his birth and the cycles of academic research have generated some recent scholarly interest, apprehending his 97year-long life spanning from early twentieth-century Johannesburg, to mid-century London and Paris, with the remainder spent in late- and post-colonial Jamaica, presents certain challenges. In fact, the relative absence of close engagement with his obscure early years in South Africa, and the writings that emerged there before his flight to London as a stoker plying the route between Suez and Bombay at the outset of World War II, has warped the critical assessment of Abrahams's achievement, obfuscating his writing's ability to encode like a cypher the material and ideological networks of the 
global 1930s and to intimate how that decade's rivalries and contradictions continue to unfurl in the present.

Born poor, the material and ideological networks that propelled Peter Abrahams to literacy in 1930s South Africa lay bare how white liberalism, Pan-Africanism, and Marxism all overlapped as well as contradicted one another in the global 1930s. The confluences and contradictions of these currents of thought, artistic production, and political action structure not only Abrahams's early life and writing, they connect him to a global portfolio of non-European migrants whose itineraries were propelled to some degree by interracial literary instruction that aspired to transcend the hierarchical social relations they in fact act out. These contradictions haunt the Cold-War-era writings which established Abrahams's international reputation, a treacherous era which saw many of his 1930 s peers such as Claude McKay, Carlos Bulosan, and Zora Neale Hurston, sink into impoverished obscurity. Abrahams's perduring reputation depended on his precarious ability to write and act from the ironic institutional conjunctures that brought together a fragile constellation of networks and positions, derived from the Popular Front politics of the global 1930s, teetering on the edge of collapse and mutual negation. Yet anachronistic readings of his political and literary entanglements, and a failure to take seriously the sites of his early literacy and youthful writings, have manhandled this fragility, overwriting as a watery liberalism his generative merging of Pan-Africanism and Marxism that remains relevant today.

Abrahams wrote of Vrededorp, his birthplace on the outskirts of Johannesburg, as a "slum-home of the dark-skinned thousands" $(1943,23)$. He grew up in extreme poverty and deprivation, the primary obstacles to his education for the first 10 unschooled years of his life. Peter's father, "James Henry Abrahams Deras, whose name in Ethiopia was Karim Abdul, son of Ingedi(e) of Addis", was an economic migrant who had made his way to South Africa to work in the mines (Abrahams 1952, 15). Like so many overworked and underpaid miners, he died young, when Peter was only just old enough to have a few memories of him. "With [my father's] going", he writes, "the order and stability that had been in my life, dissolved. There was no bread-winner so we had to leave the place that had been our home" (Abrahams 1952, 15). The death forcibly split the family apart. Peter was sent off to an aunt in rural Elsberg, where he experienced the hardship, want, freezing cold, and racism of agricultural South Africa.

As soon as Peter returned to Vrededorp, he began working. He sold bundles of firewood for his aunt, he kept a lookout for police when she ran her weekend shebeen, he hustled to carry people's bags as an unlicensed market-boy, he cleaned in a hotel, and he sold newspapers, but it was an episode from his turn working in a tin-can smithy that would radically transform his life. There, the secretary, who Peter describes as "the short-sighted Jewish girl", asked him, for the first time in his life it seemed, if he was interested in going to school and learning to read.

She turned the pages of the book in front of her. She looked at me, then began to read from Lamb's Tales from Shakespeare.

The story of Othello jumped at me and invaded my heart and mind as the young woman read. I was transported to the land where the brave Moor lived and loved and destroyed his love...

"When I can read and write I'll make stories like that!"

Her eyes looked strangely bright behind the thick glasses. 
"Go away!" she said. "Go away ... and good luck ..."

I hesitated awkwardly at the door. Was she crying? And why? (1952, 149-150).

The puzzling tears of white liberalism would continue to vex Peter from his youth to his old age. The Jewish question, furthermore, vexed the category of whiteness and troubled nearly all the ideological currents flowing through the 1930s in South Africa and the world. The autobiographical vignettes composed between 1930 and 1938 that make up the first section of Dark Testament (1942), Abrahams's first book of prose, feature many Jewish characters from Peter's youth "because the Jews", as he writes in the story "Jewish Sister", "like the dark-skinned people, are looked down upon" $(1942,33)$. The "outcast" status of Jews constituted one of the many linkages for Peter between South African politics and the international scene, as many of the Jewish characters Peter recalls were "refugees from Germany" hoping to find peace in exile but often encountering the brutal violence of Afrikaaner nationalism, as recounted in the vignette "Brother Jew" (1942, 18). The intersection of the global rise of fascism with the local rise of Afrikaaner nationalism in the 1930s had a huge influence on South African politics, structuring the antagonisms and alliances that cleave Abrahams' political consciousness, as we will explore below.

After Peter's encounter with Othello via the liberal intervention of his Jewish co-worker, Peter shows up at a grossly underfunded and overcrowded school for Coloured children run by Visser, a "mad Boer poet ... interested in Coloured education", another white liberal who puzzles the young Peter (Abrahams 1952, 152). Despite the material challenges, Abrahams identifies this initial period of literacy as crystallizing his desire to become a professional writer. A vignette entitled "I remember...", recounting an episode when students from the class had to stand up and announce what they wanted to be when they grow up, captures the stunning ambition of this desire:

I have never heard of any non-European being what I wanted to be.

"I want to be a writer."

I waited for the effect. There was none. The teacher just sat smiling at me. A strange, halfamused smile that made her look beautiful to me. She was good to look at even when she was not smiling. A light-coloured girl, who could pass for a white in a dim light.

"Why do you want to be a writer?"

My khaki shirt was torn in many places. It was very dirty. My body was not much cleaner. My khaki shorts had a great hole in the seat. Two girls behind me kept giggling at the visible part of my bottom. My feet were cracked and bleeding. It was winter. There was a bump on my head from a recent fight.

"I want to be a writer so that I can write stories about everything. You know, like the stories in books. That will make me famous, and I'll have cakes and ginger beer for breakfast, and fish and chips for lunch, and a whole fowl at night. Then I'll be able to eat three times every day, and have shoes and a motor car, and live like the rich white people do. And then I want a collar and tie. That's why I want to write stories."

For some time after she had told me to sit down the teacher laughed at me. Mostly with her eyes. 
I remember that afternoon particularly well, because I fainted shortly afterwards. It was very difficult to revive me. When I came to I had to admit that I'd only had a slice of bread in two days. They gave me food, but that only made me ill, so I was sent to the General Hospital. I stayed there for a few weeks. They said I was suffering from starvation. Then they let me out to starve again. (Abrahams 1942, 9-10)

As with the Jewish secretary, his light-skinned teacher's eyes contain a "strange" communication, a unique liberal affect of empathy, pity, and condescension. Yet the gravity of Peter's malnutrition shames the silent laughter that encodes her superiority.

This ambivalent dynamic between the pupil of colour and the white agent of literacy, cut across by affection, gratitude, pity, and condescension, links Abrahams's writing to a whole network of 1930s-1940s global Anglophone literary production, from the Jamaican Claude McKay's A Long Way from Home (1937) and Filipino Carlos Bulosan's America is in the Heart (1946) to Zora Neale Hurston's Dust Tracks on a Road (1942). Like Abrahams and his father before him, all these authors were migrants, and their itineraries were propelled to some degree by interracial literary instruction that aspired to transcend the hierarchical social relations they in fact act out. This contradiction undergirds the global 1930s Popular Front enterprise that a teenage Abrahams would join wholeheartedly, that effort to bring Anarcho-Syndicalists, trade unionists, anticolonial nationalists, Socialists, and Communists under the same anti-fascist political umbrella as capitalist Liberals and Social Democrats.

Before this public political participation, though, Peter's precarious economic situation would continue to interfere with his quest for literacy. He manages to study at Visser's school for nearly three years before he is forced to quit when his aunt is imprisoned for illegal alcohol distribution. He returned to seeking menial employment on the streets of Johannesburg. Another chance encounter with a model of advanced literacy would usher Peter into the New African world of the Bantu Men's Social Centre, a socio-cultural formation overdetermined by white liberalism and Pan-Africanism. He recounts in Tell Freedom how one afternoon, a couple years after he had had to leave primary school, sitting in a greasy Coloured diner,

a slim, neatly dressed, collar-and-tie young man stopped for coffee and fatcakes. While he ate he read a paper. I saw the paper's name: The Bantu World. I twisted my body to see better. Yes, the pictures on the front page were of black people! All the papers I sold had only pictures of white folk. (Abrahams 1952, 189)

This was Peter's first encounter with a New African, a South African borrowing from Harlem's "New Negro", who cannily warned Peter about The Bantu World that "[a]lthough it's by and about black people, it's controlled by whites" (Abrahams 1952, 189), referring to the Argus Printing and Publishing Company, which controlled "a brace of commercial black newspapers" (Sandwith 2019, 21). Impressed by Peter's literacy and spirit, the young man invited Peter to head to the Bantu Men's Social Centre where he was certain they could find some work for him.

Like The Bantu World, the Bantu Men's Social Centre that would play such a major role in Peter's life rested on contradictory foundations. The strains of Paul Robeson wafted through the air and the shelves of the library were full of "Africana" and "American Negro Literature". At the same time, however, this Black space heavily depended upon white institutions, a material contradiction undergirding a whole slew of ideological contradictions that Abrahams could lay bare but never resolve, contradictions that partly led 
McKay, Bulosan, and Hurston into embittered bitter post-WWII obscurity until their reputations were revived through the West Indian, Asian diasporic, and African American cultural militancy of the 1970s. Let us consider that presence of "American Negro Literature" at the Bantu Men's Social Centre. In what has been taken as a sort of primal scene of Black South African literature, Abrahams writes:

I turned the pages of The New Negro. These poems and stories were written by Negroes! Something burst deep inside me. The world could never again belong to white people only! Never again!

... In the months that followed, I spent nearly all my spare time in the library of the Bantu Men's Social Centre. I read every one of the books on the shelf marked: American Negro literature. I became a nationalist, a colour nationalist through the writings of men and women who lived a world away from me. $(1952,197)$

W. E. B. Du Bois, Countee Cullen, Langston Hughes, Georgia Johnson Douglas, and Jean Toomer would inspire the two volumes of poetry Abrahams published in 1930s South Africa: Here, Friend and A Black Man Speaks of Freedom! Younger South African writers would remember Abrahams precisely for his early turn to the Harlem Renaissance as a source of aesthetic inspiration, for which Ezekiel Mphahlele $(1959,129)$ "regarded him as a conqueror".

Yet much as the Harlem Renaissance struggled with questions of white patronage and voyeurism, so too did the New African movement. Just as the American Board of Missions provided the funding to establish the Bantu Men's Social Centre space, the very presence of "American Negro Literature" in their library owed its provenance to the liberal disbursements of the Carnegie Corporation of New York, Andrew Carnegie's philanthropic trust. As librarian Beverly Hinds (2008) writes from Barbados, another site of such disbursements, "Twenty-five hundred Carnegie public libraries are situated across the world, all built with money donated by Andrew Carnegie, the man known as the Patron Saint of Libraries". The Carnegie Corporation's library initiatives ironically enabled the reading networks of early twentieth-century Black internationalism, melding a liberal uplift ideology that could accommodate racist hierarchies with a sort of lazy assumption about the monolithic qualities of Black readers around the Anglophone world. Yet out of this ironic institutional conjuncture, Abrahams, like so many other global Black intellectuals, forged a generative even if internally contradictory Pan-African sensibility.

The Bantu Men's Social Centre represented a key site of Abraham's developing literacy. It emerged through complex negotiations across political, geographical, and racial divides. As Alan Cobley writes:

During the early years of the twentieth century an increasingly politicised black elite emerged in South Africa in the context of a growing segregationist climate. A critical feature and weapon of this elite was literacy. While black intellectuals regarded unrestricted access to libraries as a necessity, missionaries, white liberals, and, ultimately, the state considered the question of reading and library provision for blacks in the light of a perceived threat of radicalism from the black elite. Efforts to develop library facilities for blacks were to receive official sanction and support only after the role of libraries had been clearly defined as part of a wider context of social control. (Cobley 1997, 57)

Social control in this case took the form of what Corinne Sandwith calls "moralised leisure", with libraries and literacy serving as "a mitigating force against both hooliganism and 
political dissent" emanating out of "the unregulated and anarchic location space" of the non-European townships (Sandwith 2016, 1099). The Carnegie Corporation leaned on its late-nineteenth-century and early twentieth-century experiences in the American South, where its initiatives to support African American literacy similarly embraced a civilizing uplift ideology based on curtailing "hooliganism and political dissent". Not only were these intentions exported from the United States to South Africa (and the British West Indies as well, as Hinds mentions from the vantage point of Barbados), but the very reading material itself was identical. As Madeleine Rochester $(1999,41)$ details: "In the selection of materials for the Carnegie Non-European library services, ideas were borrowed from the United States. What had been popular with African Americans in the United States was assumed to be suitable for these libraries." The monolithic treatment of Black populations across the Anglophone world ironically laid out a textual commons for different populations of Black readers to apprehend something of their common plight, to offer new idioms of response, and to stimulate dialogue across these geographies. For Abrahams, the library of the Bantu Men's Social Centre fostered his early textual encounters with African American and West Indian writers, from W. E. B. Du Bois and Marcus Garvey to Langston Hughes, Claude McKay, and Eric Walrond. ${ }^{1}$ These textual encounters would not only shape his political outlook and literary expression in the 1930s, they anticipate his close collaboration with many of these figures once he left South Africa in 1939.

The political outlook and literary expressions shaped in this period through his readings in the Bantu Men's Social Centre contained the ideological overlaps and contradictions implicit in the conflicted establishment of this site of reading. While liberal and Black nationalist tendencies vied with one another, subsequent critics have tended to view the Carnegie Corporation's goal of "social control" to have succeeded in the case of Peter Abrahams and the New African movement. For Ntongela Masilela, the collaboration of white liberalism and "New Negro modernity" subordinated a nascent African nationalism, rooted in indigenous African languages and cultural traditions, to the emphasis on European languages and cultural traditions. Speaking of the influential leadership of Seloma Thema, founding editor of The Bantu World, over the New African movement, Masilela contends:

Tradition was synonymous with barbarism. New Negro modernity, which he absolutely adored, except for jazz which he despised like the other conservative New African modernisers, was to be the instrument with which to destroy African traditions. All the major participants in the creation of this 'new' literature-H. I. E. Dhlomo, Peter Abrahams, Walter B. M. Nhlapo, Todd Mathshikiza and Henry Nxumalo-were the acolytes of Thema, working under his guidance and being trained and/or inspired into journalism in the pages of Bantu World. (Masilela 2004, 32-33)

\footnotetext{
${ }^{1}$ Ntongela Masilela instructs us that such traffic between South Africa, the United States, and the Caribbean has a long and complex history: "In exemplary fashion, like some of his senior colleagues in the New African Movement, Nxumalo contributed articles to the Pittsburg Courier in the 1940s, as Allan Kirkland Soga had done in the 1900s to The Coloured American Magazine, as Clements Kadalie had done in the 1920s to The Messenger, and as Keorapetse Kgositsile was to do in the 1960 s to the Pan African Journal and in the 1970s to The Black World. In a reciprocal mode, Booker T. Washington had done with articles in the 1910s to John Tengo Jabavu's Imvo Zabantsundu and Solomon T. Plaatje's Tsala ea Batho (The People's Friend), Edward Blyden had done in the 1910s to Imvo Zabantsundu, George Padmore had done in the 1940s to The Torch, and Langston Hughes had done in the 1950s to Africa South and to Drum magazine. Henry Nxumalo belonged to a noble tradition of intellectual discourse across the Atlantic": Masilela 2004, 40. See also Collins-Buthelezi 2015.
} 
This focus on the modernizing tendencies of the New African movement sutures the turn to literary modernism to a watery political liberalism cut off from indigenous African resources. Laura Chrisman $(2005,267)$ similarly draws a line from Abrahams's encounter with "American literary blackness" to his "open rejection of Marxism".

In the global 1930s, however, the status of literary modernism, Black and otherwise, cannot be neatly compartmentalized politically. Abrahams's literary production during this period, before he stepped away from formal political affiliation in the 1940s, continues to reveal the overlapping and contradictory ideological strains of the moment. While curated with a liberal hand, the reading material of the Bantu Men's Social Centre also fed into Abrahams's output a Pan-African vision informed both by Du Bois, "whose words had the impact of a revelation", and Garvey $(1952,193)$. Mphahlele $(1959,128)$ remarked that Abrahams "spoke vividly about Marcus Garvey ... and dreamily he said what a wonderful thing it would be if all the negroes in the world came back to Africa". Abrahams would later intimate a precocious Garveyite vision of Black sovereignty into his childhood in rural Elsberg. For despite the poverty and deprivation, he also experienced pastoral idylls with his Zulu friend Joseph:

There was the river to explore.

There were my swimming lessons, and others.

I learnt to fight with sticks; to weave a green hat of young willow wands and leaves; to catch frogs and tadpoles with my hands; to set a trap for the springhaas; to make the sounds of the river birds...

There were Joseph's tales of black kings who lived in days before the white man. $(1952,44)$

When Joseph asked Peter who his kings were, Peter had no answer. When he pressed his mother on the question, she replied: "'On your father's side you're Abyssinian ... ' I would say to Joseph: 'I am Lee of the Abyshinins! My kings were before the days of the white man and my kings are still kings to-day!"' $(1952,51)$. Abrahams's Ethiopian roots nourish a political Ethiopianism - most fully explored in his last novel, The View from Coyaba-that he suggests ran from his early childhood to his unwavering, lifelong regard for Marcus Garvey. Garvey's message, which Abrahams $(2000,38)$ recalls was smuggled into South Africa by Black sailors passing along contraband copies of the Negro World, the newspaper of the United Negro Improvement Association (UNIA), had already started to shape the Black trade union movement under Clements Kadalie, who "established the Industrial and Commercial Union of Africa [ICU] in $1919 \ldots$ inspired by Garveyist notions of Negro selfadvancement and assertion" (Ensor 1992, 69). Literary Garveyism as well travelled to South Africa through such newspapers as the Pittsburgh Courier, which serialized George Schuyler's Black Empire in 1936.

As we saw with their concern over "hooliganism and political dissent", the white power structure used not only pass-laws and police brutality to control the rapidly growing urban population, but soft power techniques such as cultivating literacy and establishing the non-European libraries. This moral suasion, however, often created textual vehicles for just the sort of dissent they sought to crush. The Bantu World, while "controlled by whites", featured a regular column by R. R. R. Dhlomo writing under the moniker "Roamer, Esq." This local literary appropriation of the European flâneur tradition in the 
racialized city, which according to Sandwith $(2019,24)$ "places emphasis on the various forms of interdiction, prohibition and surveillance which face the would-be flaneur", became a crucial element of New African textual production, evident in the title of Mphahlele's autobiography, Down Second Avenue, but decades before that in Abrahams's first novel, Song of the City, which he began conceptualizing in South Africa years before it was published in London in 1943.

Song of the City takes place in the few days leading up to the South African government's 1939 decision whether to remain neutral (the pro-Nazi Afrikaaner position), or to join the British war effort against fascism, and features a cast of characters representing the major sectors of South African society. The novel borrows techniques made familiar to Anglophone readers through exemplars like Virginia Woolf's "Kew Gardens" and James Joyce's "Wandering Rocks" episode of Ulysses. In these pieces, the authors bring what Ortega y Gasset (1969) calls a "dehumanizing" approach to artistic representation, where the narrators self-consciously assume an omniscient and formalist perspective as people, like vectors in a dynamic field, move through an urban topography as so many atomized monads. The moral core of the novel resides in the nascent politicization of the Jewish teenager Naomi Ashe and one of her house servants, Dick Nduli. Naomi Ashe chafes against her father's pacifism, his desire to stay above political division, so as "not to be misled by power-seekers" (Abrahams 1943, 50). "But isn't your attitude like -like being a spectator", she charges, "while things are destroyed around you? It helps nobody. It's not human, father" $(1943,49)$. She will turn from her father toward the Marxist trade-unionist Roger. Nduli, on the other hand, recently arrived from the countryside, will begin his "sentimental education" on the ways of the racialized city, encountering precisely the "interdiction, prohibition and surveillance" Dhlomo regularly critiqued in his column. In this case, then, Abrahams's literary modernism, significantly enabled by the Carnegie Corporation and New African vehicles such as the Bantu Men's Social Centre and The Bantu World, yielded a "critique of 'actually existing' liberalism, whose political ineffectiveness (figured in the dreamily impractical Professor Ashe) has all too easily led to the collapse of its historic project" (Wade 1990, 93-94).

Another way in which Abrahams's outlook and output in the 1930s exceeds the liberalism imposed by the globally dominant white power structure lies precisely in the Marxist commitments his early writing from the 1930 s and early 1940 s reveal. These commitments grew out of his years of missionary education at the Anglican Diocesan Teachers' Training College (Grace Dieu) near Pietersburg and St Peter's Secondary School in Rosettenville for a year in 1937. As Catherine Woeber reports:

\footnotetext{
Both were run by the monks of the Community of the Resurrection, who came from a strong working-class environment in Yorkshire (although many of them were upper-class Oxbridge graduates), and whose radical theological and political views were usually at odds with those of the colonial establishment ... Both institutions, but particularly St Peter's, were characterised by a socialist and argumentative ethic which differed from that of other mission schools. (Woeber 1997, 89)
}

Notably, the connections Peter made at the Bantu Men's Social Centre enabled him to return to school at institutions whose political postures ran further left than the liberalism of the Carnegie Corporation and "other mission schools". In conjunction with the leftist bent pulsing throughout writers such as Langston Hughes and Claude McKay, this 
educational environment set the stage for Abrahams's encounter with Marxism, which like his discovery of Du Bois, "had the impact of a miraculous revelation" (1952, 250). Abrahams discovered Marxism through the friendship he struck up with the aforementioned "Jewish sister", a young mother who lived with her husband near St Peter's:

These had been the first white people to invite me to their home as a guest, the first white people who had sat at table with me. Gradually, over a period of time, they had nursed my friendship, had made me see that it was something they valued and desired... They had called the creed by which they lived Marxism. $(1952,250)$

Abrahams's newly discovered enthusiasm led to his involvement with left-wing political and literary activism, comprising myriad trade-union meetings, demonstrations, study groups, public lectures, and the appearance of his first poems and articles in newspapers across South Africa.

As in the rest of the world, the 1930s in South Africa witnessed an intensive, millennial political ferment where local and global issues intersected. The intensification of Afrikaaner nationalism that motivated the 1936-1938 purging of Africans and Coloureds from voter rolls followed not only local political trajectories, but were fuelled and informed by the global rise of fascist, master-race politics. Mussolini's 1935 invasion of Ethiopia of course represented another facet of this global movement, as did Franco's attempt to overthrow the Spanish republic with Mussolini and Hitler's support. The global economic downturn intensified the urgency of black and white economic and political militancy. Thus the Spanish Civil War (1936-1939) not only affected white South African passions along the Left-Right political axis, but given the concerted prohibition throughout North America and the British Empire on Blacks travelling to Ethiopia to take up arms in defence of that nation, Spain also became a proxy war against the colour-line: "It ain't Ethiopia, but it'll do", as the refrain of African American members of the Abraham Lincoln Brigade had it.

The Anglo-American effort to forestall Black militancy in Ethiopia coincided with British efforts to suppress a wave of Black labour strikes throughout the West Indies, strikes that historians read as the inception of decolonization in the Caribbean. At the same time, the British also brutally suppressed the Arab Revolt (1936-1939) for Palestinian self-determination in the face of Zionist expansion in the Holy Land. Yet not only would Jewish and Palestinian communists find common cause in the push against fascism in Spain, as Elizabeth $\mathrm{M}$. Holt has uncovered in her reading of Ghassan Kanafani, the 1930s also witnessed the rise of the potential for a "bi-national workers republic" in Palestine under Marxist auspices (Holt 2018). Tragically, the dispossession of the Palestinians by Zionist settler-colonialism in the aftermath of the Popular Front also caused a re-alignment of the Jewish question in global politics that would profoundly disturb Abrahams in the post-World War II era. But here, in the global 1930s, Abrahams-like the doomed Republican forces in Spain-would straddle the unruly plethora of identifications encompassing anti-colonialism, Pan-Africanism, Marxism, and liberal humanism legible in his writings of this period.

An emphasis on any one of these identifications obscures the potent structural ambivalence between them and threatens to overshadow how Abrahams's trajectory in literacy depends on the material and ideological networks of all of them. Both Michael Wade and Robert Ensor, for example, authors of book-length studies of Abrahams, emphasize his liberalism. Wade $(1972,5)$ claims that "Abrahams invokes and even to some extent typifies 
the liberal dilemma", while Ensor $(1992,118)$ argues that "Abrahams appropriates and reconceptualises Communist Party and African nationalist political discourse in terms of dominant liberal concepts". In the global 1930s, however, from the vantage point of Abrahams in South Africa, such emphases on liberalism are anachronistic and tend to oversimplify the ambition of Abrahams's poetry and praxis.

This ambition somewhat aligns, albeit discrepantly at times, with the aspirations of the Popular Front, that herculean attempt to hold together an anti-fascist coalition encompassing Marxism, capitalist liberalism, and anti-imperialism. Abrahams's volume A Blackman Speaks of Freedom! takes the lead especially from Langston Hughes's agitprop poetry of the 1930s: one of the book's epigraphs reprints the latter's "I, Too" in its entirety, while the others cite Paul Potts, "Canadian Folk Poet", and Federico García Lorca, murdered by Franco's forces in Andalucía. The vernacular internationalism of these epigraphs position Abrahams as what Ismail Meer, in the book's foreword, calls a "PEOPLE'S POET" (Abrahams 1939, 5). Further paratextual matter reiterates this role and the audience Abrahams imagines for his verse: "This stuff is copyrighted, but not from any worker, white or black, who might be able to make use of it in any way possible" $(1939,6)$. An opening address by Abrahams, "For Laughter!", insists on crossing other boundaries of identification:

Now it may be unpatriotic, but a German boy will never be a Hun to me. An Italian will never be a Wop. Deep down we are brothers ... Just like all the segregation laws and all the attempts to prove that because my skin is black, I'm half animal, will not give me a tail or horns. $(1939,8)$

Abrahams continues to survey the global 1930s beyond Europe through the poems in this volume, playing notes that nod to the Black liberation struggle, the worker's struggle, and the anti-imperial struggle, recognizing both the convergences and divergences between these terrains of conflict. His poem "Freedom's Child," for example speaks through the personified nations of Asia. The first numbered stanza reads:

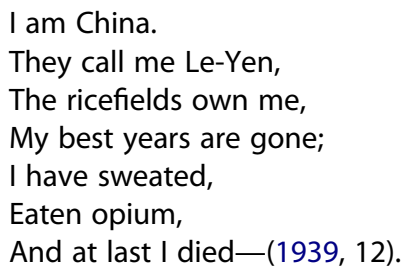

In this stanza, Abrahams addresses the class status of the peasant, working the landlord's fields, as well as his racialized colonial status, subjected to the drug-fuelled "informal empire" of the British in China. By following this stanza with one focused on Japan, he reminds readers of imperial Japan's contemporaneous occupation of Manchuria. The poem implicitly recognizes Mao Zedong, whose growing communist movement in the 1930s promises to rid China of both class and imperial domination. Abrahams returns to the promise of universal redemption through Marxist revolution after two more stanzas, one focused on India ("a jewel. / The brightest in a crown / of a foreign king." [12]), and another on South Africa ("I am the gold mines / paying huge dividends / ... / Fashioned out of beads of sweat of black men" [13]). In the final stanza, he writes:

The master beasts are marching to death-

I heard it whispered in a dying breath. 
The whisper was caught by the Proletarian breeze

And carried away across the seas, And every sufferer heard the voice, And in quiet I heard the wind Rejoice. $(1939,14)$

Riffing on the master race/blond beasts of Fascism, Abrahams envisions Blitzkrieg instead as their own suicide, followed by the soothing strains of Romantic prosody predicting the coming of "Freedom's Child".

Abrahams published A Blackman Speaks of Freedom! in the port city of Durban, where he travelled to after some time in Cape Town in order to seek his freedom abroad. He had already gained notoriety throughout South Africa for his poems and combative articles published in the Bantu World, the Cape Guardian, and other publications. While in Durban he helped edit The Call, a monthly bulletin published by the Liberal Study Group, an Indian nationalist organization. In his 2000 autobiography, he would recall how this bulletin relied on the efforts of the Trinidadian activist George Padmore, whom he met in London shortly after his arrival there in 1941:

Padmore was a totally political animal. His work room had one large table piled high with books and papers and a large old office typewriter that could make many copies at once. On that old machine he typed his 'dispatches' which were sent to the small local newspapers and magazines in Africa, Asia, the Americas and the Caribbean. I had used some of the Padmore dispatches when I edited a cyclostyled little magazine in Durban for the largely Indian Liberal Study Group. All the Padmore dispatches said 'please pass on to other periodicals'. This was the way most of the independent little papers and magazines in the colonies received a non-European perspective on what was happening in the world. (Abrahams 2000, 38)

Outside the officially sanctioned Carnegie "book deposits" filling the shelves of non-European libraries and reading rooms, Abrahams draws our attention to another site of reading that flies in the face of official channels of circulation and reproduction, just as smuggled copies of Garvey's Negro World would inspire Black nationalists and trade-unionists. The state would take notice:

The meetings of the Liberal Study Group aroused the interests of the police. One day in August I was called down to the police station. The white sergeant who had attended many of our meetings questioned me.

“Now Abrahams you're no fool. I don't know why you mess around with these Coolies. None of your other Coloureds do."

"They're South Africans just like you and me, sergeant." $(1952,304)$

The potential of an alliance between the subordinated non-European groups of South Africa, of course, threatened the security of white supremacy, a theme taken up in Abrahams's A Night of Their Own (1965). It was precisely Abrahams's work with the Non-European United Front in Cape Town that had brought him into contact with the Liberal Study Group. The United Front formed in 1938 to protest the purging of Coloureds from the Cape voting rolls. When in 1936 the government had purged Africans from the rolls, the African National Congress and the All African Convention "had called on the Coloureds 
for joint action", only "a miserably small handful" heeded the call (Abrahams 1952, 279). Despite this previous slight, and perhaps demonstrating the greater spirit of Popular Front coalition building accumulating as World War II approached, "a monster demonstration" was held on the Cape Town parade ground. In one of the most climactic moments of Tell Freedom, the meeting transforms into a procession to Parliament and ultimately a "seven day sensation throughout the country" $(1952,282)$.

This model of collective action, this coming together across racial barriers, class lines, and national origins, inspired Abrahams and found its echo in the anti-fascist demonstrations before Parliament in Song of the City, as crowds gathered in anticipation of the vote whether or not to enter the war on the side of the British. Abrahams $(2000,31)$ found elements of this Popular Front spirit alive in London during the war years: "The mood of a shared enterprise in defence of freedom was tangible". Colonial subjects shared in this enterprise, despite their subordinate status:

the teeming colonial subjects of that empire did not, on the whole, want England to lose that war, but they also did not want the empire to emerge unchanged from it. This, for very many of us, was the hard dilemma. $(2000,27)$

London seemed to offer a vision of a reformed sociality in the imperial metropole:

This, looking back, was the seedbed of the later unity of African, American and Caribbean black folk. The students got to know each other personally. They had a West African Students' Unions and a West Indian Students' Union. They shared classes, meals, parties. There were very few women students from Africa and the Caribbean in those early days, so they dated English young women, as well as the large body of European refugee students, mainly Jews who had fled the Nazis. (Abrahams 2000, 36)

Appropriately, in light of Abrahams's quest for literacy that would take him from Vrededorp to London, schools, student unions, and other sites of reading would foster and mediate precisely the expansive alliances he aspired to. His first hosts in London were an apartment of young Communist Englishwomen whose "single home-made bookshelf" contained "all 'Left Book Club' editions" $(2000,28$.) These would have been a familiar sight to Abrahams, as the Left Book Club, according to Sandwith "took root" with "speed and success" in South Africa:

By 1939, discussion groups had been established across the country in most major towns, including Bulawayo in Rhodesia. The South African Left Book Club reiterated the aims of the parent organization, namely "to help in the struggle for world peace, and a better social and economic order and against Fascism." (Sandwith 2013, 290)

These Popular Front literary linkages, though, uniting colony and metropole, white and Black, communist and liberal, also constantly revealed their cracks. Already in South Africa Abrahams had "found subtle and dangerous complications as I had moved deeper into th[e] Marxist world. I had found two major factions: Trotskyists and Stalinists. To each, the other was the greater enemy, greater even than the racialism of the land" (1952, 251). Abrahams's mentor George Padmore, with whom he would collaborate closely in London, especially on the epochal 1945 Fifth Pan-African Congress in Manchester, had "turned away in disgust from the communist hypocrites" when in the face of Hitler's rise the Soviet Union prioritized its alliance with the European and Anglo-American white working and middle-classes over its commitments to the anti-colonial cause 
(Padmore 1956, 147). Subsequently, as Padmore (1956, 147) would write, "the leftish members of the International Service Bureau ... oriented themselves to Pan-Africanism as an independent political expression of Negro aspirations for complete national independence from white domination-Capitalist or Communist". As Padmore observed the tectonic geo-political fractures threatening the interracial integrity of the Popular Front, Abrahams would witness a homologous fracture when he lectured at the English Working Men's Club in London. While in South Africa "only the Marxists had seemed wholly free of any taint of racialism in their dealings with me and other non-Europeans", he encountered in English working class leftism such implicit "justification for the 'colour bar"' that it "left him depressed for days" (Abrahams 2000, 44). Even Abrahams's oldest interracial alliance, with the Jews, would swiftly change in the 1940s, once "Israel, with its surprising and distressing brand of racism", would seize the mantle of world Jewry:

Such people are not expected to become racists when they throw off the yoke of racism. That was the conventional wisdom. It is not all that true or wise. Suffering, exploitation, discrimination do not confer special wisdom or understanding. They only teach how to do it to others; how to be racist; how to brutalise the weak and the vulnerable. $(2000,21-22)$

Abrahams had not been blind to the tensions, fractures, and contradictions structuring the ideological terrain that ushered him into literacy in the global 1930s. Yet his writings from and about this period lean toward a careful optimism about this ideological balancing act, articulated in his poetic insistence on the possibility of an anti-colonial Marxist humanism that could overcome the factionalism of Stalinist and Trotskyist, Jew and Arab, white and non-European. Yet "the arrival of the Cold War", as Patrick Iber $(2015,3)$ writes, "meant that the Left's internal conflicts would be inscribed onto superpower competition, and thus that struggles for justice around the world would be refracted through the imperial interests of the United States and the USSR". As the Cold War "intercepted, interrupted, and invaded" the struggle for decolonization (Chen 2010, 119), Abrahams would never resolve comfortably into an ideological camp, borrowing something of the "radical skepticism" of the Jamaica that would be his adopted home from 1959 until his violent death in 2017 (Francis 2017). Even as one of major publicists of the anti-colonial and anti-apartheid struggle, he would cast himself as "the loving critic within the PanAfrican family" (Abrahams 2000, 162). This turn to the loneliness of the writer, alongside the persistent traces of the lost possibilities of the 1930s, may perhaps account for his work's current untimeliness, his out-of-print status. Though such contradictions were apparent from the earliest appearance of the fruits of his extraordinary quest for literacy, perhaps they hold up a mirror to facets of the present we would rather not consider.

\section{Disclosure statement}

No potential conflict of interest was reported by the author.

\section{References}

Abrahams, Peter. 1939. A Blackman Speaks of Freedom!. Durban: Universal Printing Works.

Abrahams, Peter. 1942. Dark Testament. London: George Allen and Unwin, Ltd.

Abrahams, Peter. 1943. Song of the City. London: Dorothy Crisp.

Abrahams, Peter. 1952. Tell Freedom. London: Faber \& Faber. 
Abrahams, Peter. 2000. The Coyaba Chronicles: The Black Experience in the 20th Century, An Autobiography and Meditation. Bloomington: Indiana University Press.

Chen, Kuan-Hsing. 2010. Asia as Method: Toward Deimperialization. Durham: Duke University Press.

Chrisman, Laura. 2005. "Beyond Black Atlantic and Postcolonial Studies: The South African Differences of Sol Plaatje and Peter Abrahams". In Postcolonial Studies and Beyond, edited by Ania Loomba, Suvir Kaul, Matti Bunzl, Antoinette Burton, and Jed Esty, 252-271. Durham: Duke University Press.

Cobley, Alan. 1997. "Literacy, Libraries, and Consciousness: The Provision of Library Services for Blacks in South Africa in the Pre-Apartheid Era". Libraries \& Culture 32(1): 57-80.

Collins-Buthelezi, V. J. 2015. "Caribbean Regionalism, South Africa, and Mapping New World Studies". Small Axe: A Caribbean Journal of Criticism 19(1): 37-54.

Ensor, Robert. 1992. The Novels of Peter Abrahams and the Rise of African Nationalism. Essen: Die Blaue Eule.

Francis, Donette. 2017. "Radical Skepticisms: Literatures of the Long Jamaican 1960s". Small Axe: A Caribbean Journal of Criticism 21(3): 48-62.

Hinds, Beverly. 2008. "Historicising the Carnegie Free Library: The Case of Barbados". World Libraries 18(1).

Holt, Elizabeth M. 2018. "Cold War Colonialism: Arthur Koestler, Ghassan Kanafani, and Palestine". Paper presented at the annual meeting of the American Comparative Literature Association, Los Angeles, California, March 30.

Iber, Patrick. 2015. Neither Peace nor Freedom: The Cultural Cold War in Latin America. Cambridge: Harvard University Press.

Masilela, Ntongela. 2004. "Peter Abrahams in the Modern African World". Current Writing: Text and Reception in Southern Africa 16(2): 31-46.

Mphahlele, Ezekiel. 1959. Down Second Avenue. London: Faber \& Faber.

Ogungbesan, Kolawole. 1979. The Writings of Peter Abrahams. New York: Africana Publishing Company.

Ortega y Gasset, José. 1969. The Dehumanization of Art and Other Essays on Art, Culture, and Literature. Princeton: Princeton University Press.

Padmore, George. 1956. Pan-Africanism or Communism? The Coming Struggle for Africa. London: Dennis Dobson.

Rochester, Maxine K. 1999. "The Carnegie Corporation and South Africa: Non-European Library Services". Libraries \& Culture 34(1): 27-51.

Sandwith, Corinne. 2013. "'Yours for Socialism: Communist Cultural Discourse in Early Apartheid South Africa". Safundi 14(3): 283-306.

Sandwith, Corinne. 2016. "The Idea of Reading in Early 20th-Century South Africa". Journal of South African Studies 42(6): 1095-1108.

Sandwith, Corinne. 2019. "Reading and Roaming the Racial City: R. R. R. Dhlomo and The Bantu World". English in Africa 45(3): 17-39.

Wade, Michael. 1972. Peter Abrahams. London: Evans Brothers.

Wade, Jean-Phillippe. 1990. "Song of the City and Mine Boy: The 'Marxist' Novels of Peter Abrahams". Research in African Literatures 21(3): 89-101.

Woeber, Catherine. 1997. "A Long Occupation of the Mind: Peter Abrahams's Perspective on His Education". English in Africa 24(2): 87-104. 